\title{
Perizinan Tenaga Kerja Asing, Kebijakan dan Implementasinya
}

\author{
Nurhidayati \\ Universitas Bina Sarana Informatika/Administrasi Perkantoran \\ e-mail: nurhidayati.nht@bsi.ac.id

\begin{tabular}{ccc}
\hline Diterima & Direvisi & Disetujui \\
03-09-2019 & $20-09-2019$ & $24-09-2019$ \\
\hline
\end{tabular}

\begin{abstract}
Abstrak - Penyederhanaan perizinan tenaga kerja asing (TKA) yang masuk ke Indonesia adalah sebagai -salah satu upaya yang dilakukan oleh Pemerintah Indonesia dalam rangka mendatangkan investasi asing untuk membiayai pembangunan nasional. Masuknya investasi asing selalu terkait dengan masuknya tenaga kerja asing ke Indonesia. Regulasi mengenai tenaga kerja asing diatur dalam Undang-Undang No.13 Tahun 2003 tentang Ketenagakerjaan. Untuk melaksanakan undang-undang tersebut dibuatlah Peraturan Presiden, Peraturan Menteri Tenaga Kerja, serta Keputusan Menteri Tenaga Kerja. Penelitian ini bertujuan untuk mengetahui tentang perizinan tenaga kerja asing dan peraturan perundangan yang mengaturnya serta pelaksanaan tentang perizinan tenaga kerja asing. Penelitian ini bersifat deskriptif kualitatif melalui pendekatan yuridis normatif.. Data diperoleh melalui studi kepustakaan. Hasil penelitian menunjukkan prosedur perizinan tenaga kerja asing saat ini lebih mudah karena dapat dilakukan secara Online. Meskipun undang-undang dan peraturan pelaksananya mengatur secara ketat tentang persyaratan bagi tenaga kerja asing. Dalam prakteknya masih terjadi pelanggaran perizinan dan penggunaan tenaga kerja asing. Banyak tenaga kerja asing yang tidak memenuhi syarat sebagai tenaga kerja seperti buruh kasar (unskills worker) bekerja di Indonesia, dan hal ini justru terkait dengan proyek pemerintah (turnkey Project) yang disepakati bersama dengan Pemerintah Tiongkok, sehingga menimbulkan keresahan masyarakat Indonesia. Untuk mengatasinya perlu pengawasan secara ketat dari berbagai institusi yang terkait serta membatasi tenaga kerja asing yang masuk Indonesia. Selain itu perlu memperkuat pendidikan sekolah kejuruan dan pendidikan vokasi, sehingga banyak usia produktif yang trampil dalam bekerja.
\end{abstract}

Kata Kunci: Perizinan, Tenaga Kerja Asing, Regulasi

Abstract - Simplification of licensing foreign workers in Indonesia as one of the efforts undertaken by the Government of Indonesia in order to bring in foreign investment to finance national development. The entry of foreign investment is always associated with the entry of foreign workers into Indonesia. Regulations regarding foreign workers are regulated in Act No. 13 of 2003 concerning Manpower. To implement the law, a Presidential Regulation, Minister of Manpower Regulation, and Minister of Manpower Decree are made. This study aims to find out about foreign labor licensing and the laws and regulations that govern it and the implementation of foreign labor licensing. This research is a qualitative descriptive through a normative juridical approach. Data obtained through library research. The results of the study show that the licensing procedure for foreign workers is now easier because it can be conducted online. Although the law and the implementing regulations strictly regulate the requirements for foreign workers, in practice, there are still violations of licensing and the use of foreign workers. Many foreign workers who do not qualify as expatriate such as unskilled laborers ( unskill s worker) work in Indonesia, and this is precisely related to the government project ( turnkey Project) that was mutually agreed with the Chinese Government, thus causing unrest in the Indonesian people. To overcome this, close supervision is needed from various related institutions as well as limiting foreign workers entering Indonesia. In addition it is necessary to strengthen vocational school education and vocational education, so that people whom still in productive age to be skilled at work.

Keywords : Licensing , Labor Employment of Foreign, Regulation

\section{PENDAHULUAN}

Tenaga kerja memiliki peranan yang penting dalam pelaksanaan pembangunan nasional. Tenaga kerja sendiri sebagai pelaku dan tujuan pembangunan. Tujuan pembanguan nasional seperti dalam undangundang adalah membangun manusia Indonesia seutuhnya dan masyarakat Indonesia. Salah satu upaya membiayai pembanguan yang sedang digiatkan di
Indonesia dengan menarik investasi asing masuk ke Indonesia. Masuknya investasi asing sering kali dibarengi juga masuknya tenaga kerja asing ke Indonesia. Hal ini sejalan dengan komitmen Indonesia sebagai anggota MEA ( Masyarakat Ekonomi Asean) maupun sebagai anggota WTO ( World Trade Organization) untuk memberi kebebasan masuknya tenaga kerja asing bekerja di Indonesia. Masuknya 
tenaga kerja asing di Indonesia tentunya harus disertai dengan peraturan yang menyeluruh dan komprehensif. Peraturan mengenai penggunaan tenaga kerja asing di Indonesia tidak diatur tersendiri, tetapi merupakan bagian kompilasi dari Undang-Undang No.13 Tahun 2003 tentang ketenagakerjaan, yang dimuat di bab VIII pasal 42 sampai 49 yang mengatur kewajiban pemberi kerja yang menggunakan tenaga kerja asing harus memiliki izin tertulis, rencana penggunaan tenaga kerja asing, jenis jabatan dan standar kompetensi tenaga kerja asing, penunjukan warga negara Indonesia sebagai pendamping tenaga kerja asing, melakukan pendidikan dan pelatihan bagi tenaga kerja Indonesia, serta kewajiban pemberi kerja memulangkan tenaga kerja asing setelah hubungan kerjanya berakhir. Peraturan ketenagakerjaan ini diperkuat dengan Peraturan Presiden No. 20 Tahun 2018 tentang penggunaan tenaga kerja asing. Dalam Peraturan disebutkan bahwa tenaga kerja yang datang di Indonesia untuk menduduki jabatan tertentu, dengan demikian tidak membolehkan ada tenaga kerja yang tidak memiliki ketrampilan, karena dalam undangundang sudah jelas disebutkan harus ada alih teknologi dan alih keahlian dari tenaga kerja asing ke tenaga kerja Indonesia. Akan tetapi dalam prakteknya masih ada pelanggaran tehadap peraturan perizinan dan penggunaan tenaga kerja asing. Karena itu penelitian ini akan membahas tentang perizinan tenaga kerja asing: kebijakan yang sudah ditetapkan pemerintah serta pelaksanaannya.

\section{1 Perizinan}

Izin merupakan instrument yuridis yang digunakan oleh pemerintah untuk mempengaruhi para warga agar mau mengikuti cara yang dianjurkannya guna mencapai suatu tujuan konkret (Ridwan HR, 2010). Selanjutnya disebutkan tujuan perizinan adalah

a. Keinginan mengarahkan atau mengendalikan aktivitas-aktivitas tertentu (misalnya izin bangunan).

b. Izin mencegah bahaya bagi lingkungan (izin-izin lingkungan).

c. Keinginan melindungi objek-objek tertentu (izin membongkar pada monumen-monumen)

d. Izin hendak membagi benda-benda yang sedikit (izin penghuni di daerah padat penduduk).

e. Izin memberikan pengarahan dengan menyeleksi orang-orang dan aktivitas-aktivitas (izin berdasarkan "drank en horecawet" dimana pengurus harus memenuhi syarat-syarat tertentu).

Perizinan menurut Bidara (Sutedi, 2014) adalah dispensasi atau pelayanan/pembebasan dari suatu larangan. Dengan demikian perizinan adalah sarana yang digunakan pemerintah untuk membebaskan warga negara melakukan sesuatu guna mencapai tujuan. Fungsi perizinan menurut Ridwan HR (Sutedi, 2014) adalah

1. Instrumen rekayasa pembangunan,pemerintah dapat membuat suatu regulasi dan keputusan yang memberikan insentif bagi pertumbuhan sosial ekonomi.

2.Fungsi keuangan (budgetering), yaitu menjadi sumber pendapatan bagi Negara.

3.Fungsi pengaturan (regular), yaitu menjadi instrument pengaturan tindakan dan perilaku masyarakatan.

1.2 Tenaga Kerja

Menurut (Hakim, 2009) Tenaga Kerja Asing adalah tiap orang bukan warga negara Indonesia yang mampu melakukan pekerjaan, baik di dalam maupun di luar hubungan kerja, guna menghasilkan jasa atau barang untuk memenuhi kebutuhan masyarakat. Tenaga kerja asing menurut (Sumarprihatiningrum, 2006) adalah orang asing yang bukan warga negara Indonesia, karena kemampuan dan kualifikasi yang dimilikinya sangat dibutuhkan untuk melakukan kegiatan dan atau pekerjaan di dalam negeri guna memenuhi kebutuhan masyarakat. Tenaga kerja asing menurut (Indonesia, n.d.-e) Undang-Undang No. 13 Tahun 2003 tentang ketenagakerjaan menyebutkan bahwa Tenaga kerja asing adalah warga negara asing pemegang visa dengan maksud bekerja di wilayah Indonesia.

\subsection{Dasar Hukum tentang Tenaga Kerja Asing} (TKA)

Peraturan yang menjadi dasar hukum bagi tenaga kerja asing adalah

a.Undang-Undang No 13 Tahu 2003 tentang Ketenagakerjaan.

Pengaturan tentang tenaga kerja asing dimuat dalam bab VIII pasal 42 sampai 49.Dalam Undang-Undang tersebut menyebutkan bahwa Pemberi kerja yang akan menggunakan tenaga kerja asing harus mempunyai rencana penggunaan yang mencakup alasan, jabatan yang akan diduduki, jangka waktu, serta harus ada yang mendampingi dari tenaga kerja warga Indonesia. Rencana penggunaan tenaga kerja asing ini harus disahkan oleh Menteri, dan sebagai persyaratan untuk mendapatkan izin kerja. Tenaga kerja asing harus memiliki standar kompetensi dan kualifikasi pengetahuan, keahlian, keterampilan di bidang tertentu, dan pemahaman budaya Indonesia. Pendampingan terhadap tenaga kerja asing menitikberatkan pada alih teknologi dan alih keahlian agar tenaga kerja pendamping tersebut dapat memiliki kemampuan sehingga pada waktunya diharapkan dapat mengganti tenaga kerja asing yang didampinginya. Tenaga kerja asing dilarang menduduki jabatan personalia dan jabatan tertentu yang diatur dengan Keputusan Menteri. setelah hubungan kerja berakhir Pemberi kerja wajib memulangkan tenaga kerja asing ke negara asalnya .

b. Peraturan Menteri Tenaga Kerja Nomor 16 Tahun 2015 tentang Tata Cara Penggunaan Tenaga Kerja Asing

Persyaratan tenaga kerja asing dimuat dalam (Indonesia, n.d.-c) bab V Pasal 6 antara lain 
disebutkan bahwa tenaga kerja asing wajib memiliki pendidikan dan sertifikasi kompetensi serta pengalaman kerja selama 5 tahun sesuai dengan jabatan yang akan didudukinya, wajib mengalihkan keahliannya kepada tenaga kerja pendamping dan dibuktikan dengan laporan pelaksana pendidikan dan pelatihan, memiliki NPWP dan kartu jaminan sosial bagi tenaga kerja yang bekerja lebih dari 6 bulan, memiliki bukti polis asuransi. Persyaratan di atas tidak berlaku bagi pekerjaan yang bersifat darurat atau mendesak..Pemberi kerja yang menggunakan tenaga kerja asing wajib mempunyai Izin Mempekerjakan Tenaga Kerja Asing (IMTA) berlaku juga bagi tenaga kerja asing yang menduduki jabatan sebagai anggota direksi, dewan komisaris atau anggota pembina, anggota pengurus, anggota pengawas yang berdomisili di luar negeri. Pemberi kerja tenaga yang mempekerjakan 1 (satu) orang tenaga kerja asing harus dapat menyerap tenaga kerja Indonesia sekurang-kurangnya 10 (sepuluh) orang pada perusahaan pemberi kerja tenaga kerja asing.

c. Peraturan Menteri Tenaga Kerja Nomor 35 Tahun 2015 tentang Tata Cara Penggunaan Tenaga Kerja Asing.

Peraturan ini (Indonesia, n.d.-d) tentang penggunaan tenaga kerja asing lebih longgar dibanding Permenaker no.16 Tahun 2015, karena menghapus Pasal 3 ayat (1) yang mensyarakatkan perusahaan untuk merekrut 10 tenaga kerja Indonesia setiap merekrut 1 tenaga kerja asing. Namun ada hal baru dari Permenaker ini yaitu ketentuan bahwa Pemberi kerja tenaga kerja asing yang berbentuk penanaman modal dalam negeri dilarang mempekerjakan tenaga kerja asing dengan jabatan komisaris.

d.Peraturan Presiden No.10 Tahun 2018 tentang Tata cara penggunaan tenaga kerja asing.

Berdasarkan Perpres ini, setiap pemberi tenaga kerja yang mempekerjakan tenaga kerja asing wajib mengutamakan penggunaan tenaga kerja Indonesia pada semua jenis jabatan yang tersedia. Dalam hal jabatan sebagaimana yang dimaksud belum dapat diduduki oleh tenaga kerja Indonesia, jabatan tersebut dapat diduduki oleh tenaga kerja Asing. Pasal 2 ayat (1) jo Pasal 5 ayat (1) menyebutkan bahwa tenaga kerja asing yang bekerja di Indonesia hanya untuk jabatan tertentu saja dan dilarang menduduki jabatan personalia. Pengusaha yang akan mempekerjakan tenaga kerja asing cukup mengajukan Rencana Penggunaan Tenaga Kerja Asing (RPTKA) tanpa harus mengajukan Ijin Menggunakan Tenaga Kerja Asing (IMTA) karena berdasarkan Pasal 9 Perpres No.10 Tahun 2018, pengesahan RPTKA merupakan IMTA.

e. Peraturan Menteri Tenaga Kerja Nomor 10 Tahun 2018 tentang Penggunaan tega kerja asing

Peraturan menteri ini sebagai pelaksana ketentuan Pasal 42 ayat (1), Pasal 43 ayat (4), Pasal 44 ayat (2) Undang-Undang No.13 Tahun 2003 tentang
Ketenagakerjaan dan Peraturan Presiden No.20 Tahun 2018.

\section{METODOLOGI PENELITIAN}

Penelitian ini merupakan penelitian deskriptif kualitatif yaitu mengungkap fakta atau kejadian yang sedang berlangsung yang bertujuan membuat gambaran, atau lukisan secara sistematis, faktual dan akurat mengenai fakta-fakta, sifat-sifat serta hubungan antar fenomena yang diselidiki. Melalui pendekatan yuridis normatif yaitu menganalisis terkait norma norma hukum yang mengatur. Metode pengumpulan datanya melalui studi pustaka.

\section{HASIL DAN PEMBAHASAN}

\subsection{Perizinan Tenaga Kerja Asing (TKA)}

Peraturan yang mengatur tata cara penggunaan tenaga kerja asing yaitu Peraturan Menteri Tenaga Kerja No. 10 Tahun 2018 menyebutkan bahwa Pemberi kerja tenaga kerja asing adalah badan hukum atau badan-badan lainnya yang mempekerjakan TKA dengan membayar upah atau imbalan dalam bentuk lain. Selanjutnya disebutkan bahwa Pemberi kerja meliputi:

a. Instansi pemerintah, perwakilan negara asing, badan-badan internasional, dan organisasi internasional.

b. Kantor perwakilan dagang asing, kantor perwakilan perusahaan asing, dan kantor berita asing yang melakukan kegiatan di Indonesia

c. Perusahaan swasta asing yang terdaftar di instansi yang berwenang

d. Badan hukum yang didirikan berdasarkan hukum Indonesia dalam bentuk Perseroan Terbatas atau Yayasan

e. Lembaga sosial, lembaga keagamaan, dan lembaga pendidikan

f. Usaha Jasa Impresariat; atau badan usaha sepanjang tidak dilarang undang-undang

Setiap tenaga kerja asing, yang akan dipekerjakan pemberi kerja harus memenuhi syarat syarat tertentu seperti tertuang dalam Pasal 5 Permenaker No. 10 tahun 2018 yaitu

a. Wajib memiliki Pendidikan dan sertifikasi kompetensi atau pengalaman kerja paling sedikit 5 (lima) tahun sesuai dengan kualifikasi jabatan yang akan diduduki.

b. Wajib mengalihkan keahliannya kepada tenaga kerja pendamping

c. Wajib memiliki Nomor Pokok Wajib Pajak (NPWP) bagi tenaga kerja asing yang bekerja lebih dari 6 (enam) bulan serta memiliki izin tinggal terbatas (ITAS) untuk bekerja yang diterbitkan instansi yang berwenang

Pemberi Kerja yang mempekerjakan tenaga kerja asing wajib memiliki Rencana Penggunaan Tenaga Kerja Asing (RPTKA) yang disahkan oleh Menteri atau pejabat yang ditunjuk, membayar DKP-TKA 
yaitu kompensasi yang harus dibayar oleh Pemberi Kerja atas penggunaan tenaga kerja asing sebagai Penghasilan Negara Bukan Pajak (PNBP) atau Penerimaan Daerah, wajib mengikutsertakan dalam program asuransi yang bekerja kurang dari 6 (enam) bulan, serta program jaminan sosial nasional.bagi TKA yang bekerja paling singkat dari 6 (enam) bulan, menunjuk Tenaga Kerja Pendamping dalam rangka alih teknologi dan keahlian, melaksanakan pendidikan dan pelatihan bagi Tenaga Kerja Pendamping, memfasilitasi pendidikan dan pelatihan Bahasa Indonesia kepada TKA yang dipekerjakannya Pendampingan dan pelatihan bahasa Indonesia dikecualikan bagi TKA yang pekerjaannya bersifat Darurat dan Mendesak, Sementara, anggota direksi, anggota dewan komisaris, anggota pembina, anggota pengurus, dan anggota pengawas. (Pasal 4 Permenaker No.10 Tahun 2018)

\section{Pendaftaran Online Pengguna TKA untuk mendapatkan Akun}

a.Pengguna TKA mengajukan permohonan pendaftaran secara Online melalui website melalui https://tka-online.kemnaker.go.id dengan mengisi NPWP

b.NPWP secara otomatis divalidasi oleh Sistem Informasi Pelayanan Pengguna TKA Online (SIPPTKA)

c. Pengguna TKA melengkapi daftar isian

d. E-mail Pengguna TKA secara otomatis divalidasi SIPPTKA

e. Pengguna TKA membuka tautan verifikasi yang dikirimkan SIPPTKA melalui e-mail

f. Verifikator memeriksa kelengkapan data isian dan dokumen permohonan pendaftaran pengguna TKA

g.Pengguna TKA dapat menggunakan akunnya melalui laman https://tka-online.kemnaker.go.id

2.Rencana Penggunaan Tenaga Kerja Asing (RPTKA). Pemberi Kerja yang akan membuat RPTKA mengajukan permohonan kepada Dirjen atau Direktur melalui https://tka-online.kemnaker.go.id dengan cara

a. Mengisi identitas Pemberi Kerja TKA, jumlah tenaga kerja Indonesia yang dipekerjakan; rencana penyerapan tenaga kerja Indonesia setiap tahun, rencana penggunaan TKA setiap tahun sesuai perjanjian kerja atau perjanjian pekerjaan, data Tenaga Kerja Pendamping alasan penggunaan TKA

b. Menggugah; rancangan perjanjian kerja atau perjanjian pekerjaan, bagan struktur organisasi, surat pernyataan untuk penunjukan Tenaga Kerja Pendamping, surat pernyataan untuk melaksanakan pendidikan dan pelatihan kerja bagi tenaga kerja Indonesia sesuai dengan kualifikasi jabatan yang diduduki oleh TKA; dan surat pernyataan kondisi darurat dan mendesak dari Pemberi Kerja TKA dalam hal Pemberi Kerja TKA mempekerjakan TKA untuk Pekerjaan Bersifat Darurat dan Mendesak.

c. Kementrian tenaga Kerja (Kemenaker) melakukan pemeriksaan kelengkapan dokumen. Apabila belum lengkap pemberi kerja TKA harus segera melengkapi persyaratan dokumen paling lama dalam waktu 1 (satu) hari kerja. Apabila sudah lengkap dalam waktu paling lama 2 (dua) hari kerja Dirjen atau Direktur menerbitkan pengesahan RPTKA

Permohonan RPTKA untuk pekerjaan yang bersifat darurat dan mendesak seperti pekerjaan yang tidak terencana yang memerlukan penanggulangan segera disebabkan antara lain bencana alam, kerusakan mesin utama, huruhara/ unjuk rasa/kerusuhan yang perlu segera ditangani untuk menghindari kerugian fatal bagi perusahaan dan/atau masyarakat umum, dapat dilakukan paling lambat 2 (dua) hari setelah TKA dipekerjakan di Indonesia. Proses penerbitan RPTKA tersebut oleh kementerian bisa dilakukan dalam waktu 1 (satu) hari, dengan masa berlaku RPTKA paling lama 1 bulan dan tidak dapat diperpanjang.

Demikian juga bagi Pemberi kerja yang mempekerjakan TKA untuk pekerjaan bersifat sementara seperti pembuatan film yang bersifat komersial dan telah mendapat izin, melakukan audit, kendali mutu produksi, atau inspeksi pada cabang perusahaan di Indonesia untuk jangka waktu lebih dari 1 (satu) bulan, pekerjaan yang berhubungan dengan pemasangan mesin, elektrikal, layanan purna jual, atau produk dalam masa penjajakan usaha; atau Usaha Jasa Impresariat. wajib mengajukan permohonan RPTKA. Pengesahan RPTKA untuk Pekerjaan Bersifat Sementara diterbitkan paling lama 6 (enam) bulan dan tidak dapat diperpanjang.

3.Tata Cara Permohonan Notifikasi

Pemberi Kerja TKA yang akan mempekerjakan TKA wajib melakukan permohonan Notifikasi kepada Dirjen dengan melengkapi data calon TKA melalui TKA Online dengan cara

a. Mengisi penetapan kode dan lokasi perwakilan republik Indonesia, Identitas TKA, dan jabatan TKA.

b. Mengunggah dokumen persyaratan, yaitu

1) Dokumen TKA seperti: Ijazah pendidikan, Sertifikat kompetensi atau pengalaman kerja, Pas foto berwarna berukuran $4 \times 6$, Bukti polis asuransi, Perjanjian kerja,Surat keterangan penunjukan Tenaga Kerja Pendamping,Paspor 
kebangsaan TKA (berwarna), Rekening koran/tabungan TKA atau Pemberi Kerja TKA

2) Dokumen Pemberi Kerja TKA terdiri dari Surat permohonan kepada Dirjen atau Direktur untuk pengajuan notifikasi, Surat permohonan kepada Direktur Jenderal Imigrasi untuk pengajuan Vitas (Visa Tinggal Terbatas) Surat pernyataan sebagai penjamin TKA, Nomor identitas pemberi kerja TKA (kartu tanda penduduk/paspor/izin tinggal), Surat persetujuan Rp0,00

c. Verifikasi seluruh kelengkapan dan keabsahan data oleh Direktur

Direktur akan memberi notifikasi apabila terdapat ketidaklengkapan dokumen. Pemberi kerja harus melengkapi seluruh dokumen yang diperlukan secara online dalam 1 hari kerja. Direktur dapat menolak permohonan notifikasi, apabila kualifikasi calon TKA tidak sesuai dengan jabatan yang akan diduduki calon TKA.

d. Apabila seluruh data telah lengkap, Dirjen menerbitkan Notifikasi secara online kepada Pemberi Kerja TKA paling lama 2 hari kerja yang memuat: Identitas Pemberi Kerja TKA; Identitas TKA, lokasi kerja TKA, jangka waktu berlakunya notifikasi sesuai dengan perjanjian kerja atau perpanjangan kerja TKA, kode pembayaran.

e. Setiap pemberi kerja yang mempekerjakan TKA wajib membayar Dana Kompensasi Penggunaan TKA (DKPTKA). Pembayaran ini dilakukan oleh Pemberi Kerja TKA paling lambat 1 hari sejak menerima notifikasi persetujuan penggunaan TKA.

4' Permohonan Visa Tinggal Terbatas (VITAS)

Sesuai dengan (Indonesia, n.d.-f) Undang-Undang No. 6 Tahun 2011 tentang Keimigrasian jo Peraturan Pemerintah No. 31 Tahun 2013 tentang Peraturan Pelaksana Undang-Undang No. 6 Tahun 2011 tentang Keimigrasian,maka warga negara asing yang akan bekerja di Indonesia harus memiliki Visa Tinggal Terbatas (VITAS). Jangka waktu berlakunya VITAS adalah 90 hari sejak diterbitkan. Tenaga kerja asing harus memiliki visa tinggal terbatas sebagai syarat diperolehnya Izin Tinggal Terbatas dalam rangka bekerja di Indonesia.

Tata Cara Pemberian Visa dan Izin Tinggal bagi Tenaga Kerja Asing diatur dalam (Indonesia, n.d.-b) Peraturan Menteri Hukum dan Hak Asasi Manusia No. 16 Tahun 2018 tentang Tata Cara Pemberian Visa dan Izin Tinggal bagi Tenaga Kerja Asing. Pemberian VITAS dapat dilakukan dengan cara

1. Pemberi Kerja TKA atau calon TKA mengajukan permohonan kepada Menteri Hukum dan Ham atau Pejabat Imigrasi yang ditunjuk. Melalui TKA Online. Pejabat imigrasi memproses Surat Persetujuan Visa setelah menerima notifikasi persetujuan penggunaan
TKA secara Online dari kementrian ketenagakerjaan.

2. Pejabat Imigrasi yang ditunjuk mengirimkan perintah pembayaran biaya Surat Persetujuan Visa, VITAS, ITAS, Izin Masuk Kembali dan Jasa Penggunaan Teknologi SIMKIM kepada Pemberi Kerja TKA atau calon TKA melalui surat elektronik.

3. Pejabat imigrasi akan melakukan pemeriksaan daftar pencegahan dan penangkalan dalam rangka penelitian latar belakang calon TKA dan Pemberi Kerja TKA. Penelitian tersebut dilakukan untuk mempertimbangkan kemanfaatan atau resiko akan dampak kedatangan TKA yang bersangkutan ke Indonesia

4. Selesai melakukan penelitian latar belakang calon TKA, pejabat imigrasi akan menerbitkan surat persetujuan visa. Surat persetujuan visa akan diteruskan melalui e-mail atau aplikasi visa online ke perwakilan republik Indonesia yang ditembuskan ke pemberi kerja TKA dan/atau calon TKA. Calon TKA yang berada di luar negeri harus datang ke Indonesia paling lama 60 hari setelah menerima Surat Persetujuan Visa.

5. TKA datang ke Indonesia dengan membawa dokumen-dokumen yang diperlukan seperti paspor kebangsaan yang masih berlaku. Kemudian, pejabat imigrasi melakukan wawancara dan pemeriksaan ulang daftar pencegahan dan penangkalan terhadap calon TKA. Setelah itu, dilakukan pula penelitian ulang latar belakang calon TKA.

6. Pejabat imigrasi akan menandatangani dan menyerahkan VITAS kepada calon TKA. Penyelesaian pemberian VITAS dilaksanakan dalam jangka waktu 2 hari kerja sejak paspor kebangsaan TKA diterima oleh pejabat imigrasi. jangka waktu menetap di Indonesia pada VITAS didasarkan sesuai dengan jangka waktu yang tercantum pada notifikasi tidak melebihi jangka waktu 2 (dua) tahun.

Berdasarka ketentuan Pasal 6 Peraturan menteri Hukum dan Hak Asasi Manusia Vitas saat kedatangan dapat diberikan calon TKA. Prosedur permohonannya sama dengan permohonan VITAS biasa. Namun, pejabat imigrasi perlu mengirim Surat Persetujuan Visa Saat Kedatangan ke kantor imigrasi yang membawahi Tempat Pemeriksaan Imigrasi tujuan kedatangan calon TKA.

5. Permohonan Izin Tinggal Terbatas (ITAS) 
Tenaga kerja asing yang ingin menetap dalam rangka bekerja di Indonesia selain harus memiliki VITAS juga harus memiliki ITAS (Izin Tinggal Terbatas). Peraturan yang mengatur ITAS terdapat dalam Pasal 8 disebutkan bahwa ITAS diberikan ditempat pemeriksaan Imigrasi yang ditetapkan oleh Menteri. Mekanismenya adalah

1. Memberikan Tanda Masuk berbentuk stiker yang memuat data TKA sekaligus ITAS dan Izin Masuk Kembali;

2. Memberikan ITAS elektronik melalui mekanisme pengambilan data biometrik,yang nantinya dikirim melalui sistem teknologi informasi keimigrasian (SIMKIM) kepada pemberi kerja TKA, calon TKA, divisi keimigrasian, dan kantor imigrasi.yang wilayah kerjanya meliputi tempat tinggal TKA

3.2 Sanksi bagi Pemberi Kerja yang melanggar peraturan

Pemberi kerja yang tidak mematuhi peraturan dalam menggunakan TKA akan mendapat sanksi. Penetapan sanksi diatur dalam (Indonesia, n.d.-g) Permenaker No. 10 Tahun 2018 Pasal 4 yaitu

1. Adanya penundaan pelayanan bagi Pemberi Kerja karena tidak mengikutsertakan tenaga kerja asing dalam program asuransi, program Jaminan Sosial Nasional, tidak melaporkan setiap tahun kepada Menteri terkait, tidak melaporkan berakhirnya penggunaan TKA.

2. Proses penghentian sementara proses perizinan TKA diberikan kepada Pemberi Kerja TKA yang tidak memiliki RPTKA yang disahkan oleh Menteri atau pejabat yang ditunjuk, tidak menunjuk Tenaga Kerja Pendamping dalam rangka alih teknologi dan keahlian TKA, tidak melaksanakan pendidikan dan pelatihan bagi Tenaga Kerja Pendamping, tidak memfasilitasi pendidikan dan pelatihan Bahasa Indonesia kepada TKA.

3. Sanksi administratif berupa pencabutan Notifikasi diberikan kepada Pemberi Kerja TKA yang mempekerjakan TKA pada jabatan-jabatan yang tidak boleh diisi oleh TKA atau jabatan yang tertutup bagi TKA, tidak membayar DKP-TKA untuk setiap TKA yang dipekerjakan.

Adapun jabatan jabatan tertentu yang tidak dapat diisi oleh tenaga kerja asing berdasarkan (Indonesia, n.d.-a) Keputusan Menteri Tenaga Kerja No. 40 Tahun 2012 adalah

Tabel .1

Jabatan jabatan yang tidak dapat diisi Tenaga Kerja Asing

\begin{tabular}{|l|l|l|l|}
\hline $\begin{array}{l}\text { No } \\
.\end{array}$ & Nama Jabatan & No. & Nama Jabatan \\
\hline 1. & $\begin{array}{l}\text { Direktur } \\
\text { Personalia }\end{array}$ & 11 & $\begin{array}{l}\text { Spesialis } \\
\text { Personalia }\end{array}$ \\
\hline 2 & $\begin{array}{l}\text { Manajer } \\
\text { Hubungan } \\
\text { Industrial }\end{array}$ & 12 & Penasehat Karir \\
\hline 3 & $\begin{array}{l}\text { Manajer } \\
\text { Personalia }\end{array}$ & 13 & $\begin{array}{l}\text { Penasehat Tenaga } \\
\text { Kerja }\end{array}$ \\
\hline 4 & $\begin{array}{l}\text { Supervisor } \\
\text { Pengembangan } \\
\text { Personalia }\end{array}$ & 14 & $\begin{array}{l}\text { Pembimbing dan } \\
\text { Konseling } \\
\text { Jabatan }\end{array}$ \\
\hline 5 & $\begin{array}{l}\text { Supervisor } \\
\text { Perekrutan } \\
\text { Personalia }\end{array}$ & 15 & $\begin{array}{l}\text { Perantara Tenaga } \\
\text { Kerja }\end{array}$ \\
\hline 6 & $\begin{array}{l}\text { Supervisor } \\
\text { Penempatan } \\
\text { Personalia }\end{array}$ & 16 & $\begin{array}{l}\text { Pengadministrasi } \\
\text { an pelatihan } \\
\text { pegawai }\end{array}$ \\
\hline 7 & $\begin{array}{l}\text { Supervisor } \\
\text { Pembina Karir } \\
\text { Pegawai }\end{array}$ & 17 & $\begin{array}{l}\text { Pewawancara } \\
\text { Pegawai }\end{array}$ \\
\hline 8 & $\begin{array}{l}\text { Panata Usaha } \\
\text { Personalia }\end{array}$ & 18 & $\begin{array}{l}\text { Analisis Jabatan } \\
\text { Ekpala } \\
\text { Kantor }\end{array}$ \\
\hline 9 & $\begin{array}{l}\text { Ahriri } \\
\text { Pengembangan }\end{array}$ & 19 & $\begin{array}{l}\text { Penyelenggara } \\
\text { Keselamatan } \\
\text { Kerja Pegawai }\end{array}$ \\
\hline 10 & & & \\
\hline
\end{tabular}

Sumber: Kepmenaker No. 40 tahun 2012

\subsubsection{Implementasi Kebijakan tentang Tenaga Kerja asing}

Maraknya kedatangan tenaga kerja asing di Indonesia menarik untuk diperbincangkan, mengingat masih terus diperdebatkan dikalangan masyarakat. Disatu sisi Pemerintah berkeyakinan bahwa mempermudah masuknya tenaga kerja asing akan memperbaiki iklim investasi dalam negeri, bagaimanapun Pemerintah masih butuh banyak investasi asing masuk ke Indonesia (Putera, 2018). Seperti yang dijelaskan Menteri tenaga Kerja bahwa penciptaan lapangan kerja perlu didorong dari peningkatan investasi. Kebutuhan akan investasi lantaran APBN terbatas dan tidak cukup hanya dari anggaran negara untuk menciptakan lapangan kerja. Salah satu upaya Pemerintah dalam mempermudah investasi asing adalah dengan percepatan prosedur izin bagi tenaga kerja asing, yaitu melalui Peraturan Presiden No. 20 Tahun 2018. Disebutkan bahwa Pengusaha yang akan mempekerjakan tenaga kerja asing cukup mengajukan Rencana penggunaan Tenaga Kerja Asing (RPTKA) tanpa harus mengajukan Izin menggunakan Tenaga Kerja Asing (IMTA) seperti dalam Peraturan Presiden sebelumnya No.72 Tahun 2014.

Jumlah tenaga kerja asing yang bekerja di Indonesia sampai 31 Desember 2018 menurut Dirjen Jenderal 
Pembinaan Penempatan Tenaga Kerja dan Perluasan Kesempatan Kerja Kementerian Ketenagakerjaan Maruli Apul Hasoloan berjumlah 95.335 orang Jumlah tenaga kerja asing yang banyak datang ke Indonesia adalah dari China (32.000), Jepang (13.897), Korea (9.686), India (6.895) dan Malaysia(4.667). Jumlah tersebut mengalami peningkatan dibanding tahun 2017 yang berjumlah 85.974 (CNN, 2019). Tenaga Kerja Asing di Indonesia paling banyak bekerja di sektor jasa, disusul industri, kemudian pertanian dan maritim.((Hamdani, 2019)

Penggunaan tenaga kerja asing di Indonesia meskipun secara tegas telah diatur dalam perundangundangan, dalam prakteknya sering kali terjadi pelanggaran terhadap peraturan tersebut.Data Kementerian Ketenagakerjaan (Kemenaker) mencatat Tenaga Kerja Asing yang terjaring kasus pelanggaran mencapai 1.521 pekerja sepanjang 2018 . Jumlah ini meningkat $290 \%$ dari tahun sebelumnya yang hanya 390 pekerja. Kasus pelanggaran oleh tenaga kerja asing mencakup

1. Bekerja di Indonesia tanpa memiliki Izin Mempekerjakan Tenaga Asing (IMTA), yakni mencapai 1.237 pekerja dan merupakan yang terbanyak dibanding kasus lainnya.

2. Kasus pelanggaran tenaga kerja asing terbesar kedua adalah penyalahgunaan jabatan yang melibatkan 104 pekerja. Atas tindakan pelanggaran TKA tersebut, sebanyak 1.511 pekerja telah diperintahkan keluar dari lokasi kerja dan 11 pekerja diberikan rekomendasi keimigrasian (Databoks, 2019).

Permasalahan lain dari TKA adalah banyaknya tenaga kerja asing unskill labour atau tidak memiliki keahlian/ketrampilan (buruh kasar) terutama dari negara Tiongkok. Maraknya TKA unskill Labour ke Indonesia tentunya Jika dilihat dari peraturan ketenagakerjaan yang mengharuskan TKA memiliki pendidikan dan sertifikasi potensi.ini merupakan suatu pelanggaran. Akan tetapi pihak pemerintah sendiri secara tidak langsung tidak mempermasalahkan hal tersebut. Hal ini terkait kerja sama antara Pemerintah Indonesia dengan Pemerintah Tiongkok terkait turnkey project yang bernilai 120 trilyun. (Jumarsa, 2018) Turnkey project merupakan kontrak terima jadi dimana kontrak pengerjaan, biaya dan pekerja-pekerjanya berasal dari negara Investor dan pihak Indonesia tinggal menerima hasil jadinya. Pendapat lain terkait faktor penyebab banyaknya tenaga kerja asal Tiongkok (Jazuli, 2018) antara lain :

1. Faktor keterbukaan investasi, mengingat saat ini Indonesia sedang banyak membangun dan adanya program pemerintah yang mendatangkan investor satu paket dengan tenaga kerjanya dari manager sampai buruh kasar.
2..Faktor kebijakan bebas visa. Dengan dibukanya pintu masuk orang asing tanpa visa (169 negara), maka banyak dari WN Tiongkok yang datang ke Indonesia, dan berdampak pada peningkatan pelanggaran keimigrasian.

3. Pemberlakuan Masyarakat Ekonomi ASEAN (MEA). Hal ini menyebabkan terbukanya sekat antar negara (border less) dan meningkatnya kedatangan tenaga kerja asing..

.Permasalahan diatas menimbulkan kekuatiran dan keresahan di masyarakat mengingat banyak tenaga kerja lokal yang belum mendapat kesempatan kerja. Apabila dilihat dari latar belakang dan dasar penggunaan tenaga kerja asing ada 3 (tiga) hal yang perlu digarisbawahi yaitu meningkatkan investasi dalam negeri, memperluas lapangan pekerjaan dan alih teknologi dan pendidikan bagi tenaga kerja Indonesia. Itu semua dalam rangka meningkatkan kualitas tenaga kerja dan meningkatkan kesejahteraan bagi tenaga kerja dan keluarganya sesuai dengan Undang-Undang No.13 Tahun 2003 tentang ketenagakerjaan. Untuk mencapai tujuan tersebut tidak cukup hanya dengan regulasi saja. Perlu pengawasan yang ketat terhadap tenaga kerja asing dari lembaga terkait seperti Kemenaker, Imigrasi Kepolisian dan lain lain. Selain itu perlu adanya pembatasan terhadap tenaga kerja asing, hanya yang memiliki profesi khusus atau memiliki keahlian saja, yang dapat bekerja di Indonesia, disamping itu perlu peningkatan keahlian bagi tenaga kerja dalam negeri, mengingat banyak usia produktif, dengan cara memperkuat sekolah sekolah kejuruan, pendidikan vokasi melalui kerja sama dengan industri. Harapan ke depannya masyarakat Indonesia memiliki tenaga kerja terampil, memiliki keahlian yang akan membuka kesempatan bekerja lebih luas, sehingga dapat mengurangi TKA yang datang ke Indonesia.

\section{KESIMPULAN}

Perizinan yang mengatur tenaga kerja asing mengalami beberapa kali perubahan, namun pada dasarnya semakin dipermudah dengan tujuan meningkatkan investasi dalam negeri, memperluas lapangan pekerjaan dan alih teknologi. Dalam prakteknya masih banyak pelanggaran yang terjadi baik menyangkut masalah perizinan atau tidak memenuhi persyaratan sebagai tenaga kerja.Untuk itu perlu pengawasan yang ketat dan batasan terhadap tenaga kerja asing, dan juga memperkuat pendidikan sekolah kejuruan dan pendidikan vokasi, sehingga banyak usia produktif trampil dan memiliki keahlian dalam bekerja.

\section{REFERENSI}

CNN. (2019). Kemenaker Nyatakan Jumlah Tenaga Kerja Asing hanya 90 Ribu. CNN. Retrieved from 
https://www.cnnindonesia.com/ekonomi/2019 0111230814-92-360311/kemenaker-nyatakanjumlah-tenaga-kerja-asing-hanya-90-ribu?

Databoks. (2019). Sepanjang 2018 Terjadi 1.500 Kasus Pelanggaran Tenaga Kerja Asing. Retrieved from https://databoks.katadata.co.id/datapublish/201 9/04/09/sepanjang-2018-terjadi-1500-kasuspelanggaran-tenaga-kerja-asing

Hakim, A. (2009). Dasar-Dasar Hukum Ketenagakerjaan Indonesia. Bandung.

Hamdani, T. (2019). Fakta di Balik Data Tenaga Kerja China di Indonesia. DetikFinance. Retrieved from https://finance.detik.com/berita-ekonomibisnis/d-4447281/fakta-di-balik-data-tenagakerja-china-di-indonesia/4

Indonesia, G. of. Keputusan Menteri Tenaga Kerja No. 40 Tahun 2012 Tentang Jabatan-Jabatan Tertentu Yang Dilarang Diduduki Tenaga Kerja Asing.

Indonesia, G. of. Peraturan Menteri Hukum dan Hak Asasi Manusia No.16 Tahun 2018 tentang Tata Cara Pemberian Visa dan Izin Tinggal bagi Tenaga Kerja Asing.

Indonesia, G. of. Peraturan Menteri Tenaga Kerja Nomor 16 Tahun 2015 tentang Tata Cara Penggunaan Tenaga Kerja Asing.

Indonesia, G. of. Peraturan Menteri Tenaga Kerja Nomor 35 Tahun2015 tentang Tata Cara Penggunaan Tenaga Kerja Asing.

Indonesia, G. of. Undang-Undang No.13 Tahun 2003 tentang Ketenagakerjaan.
Indonesia, G. of. Undang-Undang Nomor 6 Tahun 2011 tentang Keimigrasian.

Indonesia, G. ofp. Peraturan Menteri Tenaga Kerja Nomor 10 Tahun2018 tentang Penggunaan Tenaga Kerja Asing.

Jazuli, A. (2018). Eksistensi tenaga kerja asing di indonesia dalam perspektif hukum keimigrasian. Ilmiah Kebijakan Hukum, 12(1), 89-105. Retrieved from http://ejournal.balitbangham.go.id/index.php/k ebijakan/article/view/372

Jumarsa, A. (2018). Analisis peraturan presiden no.20 tahun 2018 tentang tenaga kerja asing no Title. Retrieved from https://www.kennywiston.com/analisisperaturan-presiden-no-20-tahun-2018-tentangtenaga-kerja-asing/

Putera, A. D. (2018). Menyoal Tenaga Kerja Asing dan Dampaknya untuk Indonesia". Kompas.Com. Retrieved from https://ekonomi.kompas.com/read/2018/04/24/ 084500726/menyoal-tenaga-kerja-asing-dandampaknya-untuk-indonesia

Ridwan HR. (2010). Hukum Administrasi Negara. Bandung: Mandar Maju.

Sumarprihatiningrum. (2006). Penggunaan Tenaga Kerja Asing di Indonesia (2006th ed.). Jakarta: Himpunan Pembina Sumberdaya Manusia Indonesia.

Sutedi, A. (2014). Hukum Perizinan Dalam Sektor Pelayanan Publik. Jakarta. 